\title{
MEMAHAMI POLA PEMBAHARUAN PAHAM KEPEMIMPINAN MANAJEMEN PERWAKAFAN DI INDONESIA
}

\author{
Oleh: Junaidi Abdullah dan Aristoni
}

\begin{abstract}
The tradition of the Indonesian Islamic community who tend to interpret the waqf as ibadahtabarru 'which has dimensions that are sunnah Award, in the realm of implementation are still heavily influenced understand professed by the majority of society itself, the local customs. In addition, it is also influenced by religious ideology, which is a habit to take legal actions, especially on the ground perwakafan orally on the basis of mutual trust to a particular person or institution, and this practice many people do before the Law No. 5 of 1960 on Basic Regulation of Agrarian and Government Regulation No. 28 Year 1977 on Land Owned perwakafan. The phenomenon of this tradition implications perwakafan in Indonesia has not experienced encouraging development for the benefit of the people, even suppose many emerging new issues such as loss of property for religious use, utilization is not appropriate designation endowments, low ability to manage so many waqf property displaced and so forth.

Pattern management leadership implementation waqf ago is still considered consumer-static, meaning that the management of property endowments are less able to provide benefits to the community, it can be seen from the model of leadership within the agency kenazhiran paternalistic and absence of adequate control, the recruitment of human resources more focused on ketokoan clerics, scholars, religious teacher regardless of professionalism, no clear operational standards empowerment and so forth. in line with the enactment of Law No. 412004 quiet Endowment and Government Regulation No. 28 Year 1977 on Land Owned perwakafan, then it started last major improvement in the management of the renewal perwakafan Indonesia understands both institutionally related empowerment, development and coaching, management kenazhiran and others.
\end{abstract}

Keywords: pattern renewal, leadership and benefaction

\section{A. Pendahuluan}

Sebagai salah satu aspek ajaran Islam yang berdimensi sosial, wakaf menempati posisi yang sangat 
penting dalam agama ini membangun suatu sistem sosial yang berkeadilan dan berkesejahteraan.Kendati demikian, tentunya ajaran wakaf disini tidaklah merupakan suatu perbuatan sosial yang hanya nampak kepada sifat kedermawaan seseorang tanpa adanya bangunan prinsip untuk kesejahteraan masyarakat banyak.Sesungguhnya wakaf memiliki peran yang cukup besar setelah zakat sebagai upaya pemberdayaan masyarakat ekonomi lemah.Jika zakat memiliki peran dalam menolong golongan lemah supaya dapat tetap hidup untuk mencukupi kebutuhan diri dkeluarganya setiap harinya, maka wakaf menduduki pada peran pemberdayaan mereka secara luas untuk meningkatkan taraf hidup dari sekedar mencukupi sehari-hari.

Perwujudan langkah strategi dalam meningkatkan taraf hidup masyarakat di atas, maka dipandang perlu meningkatkan peran wakaf sebagai lembaga keagamaan yang tidak hanya bertujuan menyediakan berbagai sarana ibadah dan sosial, melainkan juga memiliki kekuatan ekonomi yang berpotensi antara lain untuk memajukan kesejahteraan umum, sehingga perlu dikembangkan pemanfaatannya sesuai dengan prinsip syariah.

Namun kenyataannya, dalam praktik kehidupan masyarakat belum sepenuhnya berjalan tertib dan efisien, sehingga dalam berbagai kasus harta wakaf tidak terpelihara dan terlantar dan bahkan banyak yang hilang dan bersengketa dengan pihak ketiga akibat tidak adanya bukti tertulis, seperti halnya ikrar wakaf, sertifikat tanah dan lainnya. Keadaan demikian disebabkan sebagian masyarakat masih menggunakan pemahaman keagamaan seperti kebiasaan melakukan perbuatan hukum perwakafan tanah secara lisan atas dasar saling percaya kepada seseorang atau lembaga tertentu, dan memandang wakaf merupakan amal shaleh yang memiliki nilai mulia dihadapan Allah SWT tanpa harus melalui prosedur administratif terlebih sebelum adanya Undang-Undang No. 
5 Tahun 1960 tentang Peraturan Pokok Agraria dan Peraturan Pemerintah No. 28 Tahun 1977 tentang Perwakafan Tanah Milik. Kemudian penyebab lain yaitu ketidakmampuan nadzir dalam mengelola dan mengembangkan harta benda wakaf, di samping itu rendahnya kepedulian masyarakat tekait dengan keberadaan harta benda wakaf yang seharusnya dilindungi untuk kesejahteraan umum sesuai dengan tujuan, fungsi, dan peruntukan wakaf itu sendiri.

Dilihat dari jenis bendanya kebanyakan wakaf yang dilakukan oleh masyarakat Indonesia lebih banyak berupa tanah yang digunakan untuk pembangunan masjid, madrasah, mushalla, pesantren, makam dan lain sebagainya. Akan tetapi karena terbatasnya kemampuan dan sempitnya pemahaman tentang wakaf itu sendiri, sehingga berdampak pada banyaknya tanah wakaf yang tidak produktif dan bahkan tidak jarang benda-benda wakaf tersebut menjadi beban para nazhirnya.Dari realitas inilah, semenjak berlakunya Undang-Undang No. 5 Tahun 1960 tentang Peraturan Pokok Agraria dan Peraturan Pemerintah No. 28 Tahun 1977 tentang Perwakafan Tanah Milik dan lahirnya Undang-Undang No. 41 Tahun 2004 tentang Wakaf, dalam konteks ini perwakafan di Indonesia mulai terus dibenahi dengan melalui pembaharuan utamaya dalam kepemimpinan manajemen pengelolaan dan paham wakaf secara umum.

\section{B. Pola Sistem Manajemen Pengelolan Wakaf Masa Lalu dan Masa Kini}

Kebiasaan praktik yang terjadi dikalangan masyarakat jauh sebelum kehadiran peraturan perundangundangan sebagaimana telah disinggung di atas, tidak lain merupakan potret manajemen pengelolaan benda wakaf yang masih bersifat tradisional-konsumtif hal ini disebabkan pengaruh adat istiadat, di samping paham keagamaan yang sudah menggejala di masyarakat (Depag 
RI, 2007: 97). Pada ranah baik dan buruknya pengelolaan wakaf sudah barang tentu sangat ditentukan oleh pengelola (nazhir) dan sistem manajemen pengelolaan wakaf yang baik pula, sebab apabila wakaf dikelola secara profesional bukan tidak mungkin akan menjadi lembaga Islam potensial yang berfungsi mendanai dan mengembangkan perekonomian (Kasdi, 2014: 213).

Di sadari atau tidak sesungguhnya sistem manajemen pengelolaan menempati posisi yang penting dan sekaligus sebagai paradigma baru dalam dunia perwakafan di Indonesia. Jika selama ini paradigma lama dalam pengelolaan wakaf lebih menekankan pada aspek kepercayaan dan pentingnya pelestarian serta keabadian benda wakaf, maka dalam pengembangan paradigma baru sudah seharusnya wakaf lebih menitikberatkan profesionalitas dalam pemanfaatan yang lebih riil tanpa harus kehilangan keberadaan benda wakaf itu sendiri. Untuk dapat merealisasikan dalam mengembangkan aspek kemanfaatan tersebut, tentu yang sangat berperan sentral yaitu sistem manajemen pengelolaan yang diterapkan (Depag RI, 2007: 105).

Secara teoretis, pada dasarnya ilmu manajemen dibutuhkan oleh semua organisasi, karena tanpa manajemen semua usaha akan sia-sia dan pencapaian tujuan akan lebih sulit. Setidaknya ada tiga alasan utama diperlukan manajemen yaitu :pertama, untuk mencapai tujuan, artinya disini manajemen dibutuhkan untuk mencapai tujuan organisasi dan pribadi. Kedua, untuk menjaga keseimbangan di antara tujuan-tujuan yang saling bertentangan. Dalam hal ini manajemen dibutuhkan dalam rangka menjaga keseimbangan antara tujuan-tujuan, sasaran-sasaran dan kegiatan-kegiatan yang saling bertentangan dari pihak-pihak yang saling berkepentingan dalam organisasi seperti pemilik dan karyawan maupun kreditur, pelanggan, konsumen, supplier, asosiasi perdagangan, masyarakat dan pemerintah.Ketiga, untuk 
mencapai efisiensi dan efektivitas, artinya suatu kerja organisasi dapat diukur dengan dengan banyak cara yang berbeda yakni salah satu cara yang lazim ialah efisien dan efektivitas (Handoko, 1984: 6-7)

Dalam perspektif ilmu manajemen sumber daya manusia, istilah manejemen merupakan proses yang khas yang memiliki tujuan dalam mencapai suatu tujuan yang efektif dan efisien menggunakan semua sumber daya yang ada. Kata manajemen berarti pemimpin, direksi, dan pengurus yang diambil dari dari kata kerja "manage". "manage" memiliki makna mengemudikan, mengurus dan memerintah (Marzuki, tt: 1). Mengacu pendapat Terry yang dikutip oleh Syafaruddin bahwa "management performance of conceiving desired results by means of group efforts consisting of utilizing human talent and resources" dimana dapat dipahami bahwa manajemen yaitu kemampuan dalam mengarahkan dan mencapai hasil yang diinginkan dengan pemberdayaaan manusia dan sumber daya manusia (Syafaruddin, 2005: 41).

Lebih jauh, pendapat Terry di atas sesungguhnya tidak lain merupakan serangkaian proses tindakan melalui usaha orang lain dan kekuatan utama dalam sebuah organisasi yang mengkoordinasikan berbagai kegiatan serta berhubungan dengan lingkungannya. Manajemen diartikan proses mengintegrasikan sumber-sumber yang tidak berhubungan menjasi sistem total untuk menyelesaikan suatu tujuan. Dari beberapa pengertian tersebut dapat disimpulkan bahwa manajemen adaah kemampuan mengarahkan dan mencapai hasil yang diinginkan dengan pemberdayaan manusia dan sumber daya lainnya dimana saling bekerjasama antara individu dan kelompok dalam mencapai tujuan suatu organisasi (Pidarta, 1989:3).

Ditinjau dari konsep Islam, sesungguhnya Islam telah meletakkan dasar-dasar manajemen dalam mengatur kehidupan masyarakat.pernyataan tersebut dapat dilihat dalam surat an-Nur ayat 43-44 yang berbunyi : 
"Tidaklah kamu melihat bahwa Allah mengarak awan, kemudian mengumpulkan antara bagian-nagiannya kemudian dijadikannya bertindih-tindih, maka kelihatanlah olehmu hujan keluar dari celah-celahnya dan Allah (juga) menurunkan butiran-butiran es dari langit, yaitu dari gumpulan-gumpalan seperti gunung-gunung, maka ditimpahkannya (butiran-butiran) esitu kepada siapa yang dikehendaki-nya dan dipalingkannya dari siapa yang dikehendakin-nya. Kilauan kilat awan itu hamperhampir menghilangkan penglihatan. Allah mempergantikan malam dan siang, sesungguhnya pada yang demikian itu terdapat pelajaran yang besar bagi orang-orang memiliki penglihatan" (QS an-Nur: 43-43).

Penjelasan surat an-Nur ayat 43-44 di atas, menurut Muhammad Ibrahin Al-Bagdadi bahwa sebagai sebuah bentuk ketertiban dalam sistem kerja yang diperlihatkan oleh Allah SWT untuk menjadi pelajaran bagi setiap manusia yang mencermatinya. Kemudian menurut penjelasan ibnu abbas bahwa Rasulullah SAW, telah meletakan dasar-dasar manajemen dalam kehidupan umat, dan ayat di atas mempunyai relevansi dengan firman Allah SWT dalam surat al-An'am ayat 165 yang berbunyi :

"Dan Dial ah yang menjadikan kamu penguasa-penguasa di bumi dan dia meninggikan sebahagian kamu atas sebahagian (yang lain) beberapa derajat, untuk mengujimu tentang apa yang diberikan-Nya kepadamu. Sesunggunya Tuhanmu amat cepat siksaan-nya dan sesungguhnya dia maha pengampun lagi maha penyayang" (QS al-An'am $6: 165)$.

Dalam penjelasan surat al-An'am ayat 165 di atas, sesungguhnya Allah SWT menganugerahkan kekuasaan, meninggikan derajat, dan memberikan banyak hal kepada manusia untuk menguji tentang apa yang diberikan Allah SWT kepadanya. Dalam hal ini Allah SWT ingin melihat daya kemampuan manusia mengelola setiap anugerah yang 
telah diberikannya, sebab kemampuan mengelola akan menggambarkan rasa syukur yang tinggi kepada Allah SWT (Abu Abd Al-Lah Ahmad Ibn Ismail, tt : 112).

Berdasarkan pernyataan di atas, dapat disimpulkan bahwa pada dasarnya setiap pekerjaan seseorang harus membuat perencanaan dan perhitungan yang matang sehingga mencapai sasaran yang ingin dituju, karena itu suatu pekerjaan yang baik harus didasari prinsip-prinsip manajemen yang baik pula yang dimulai dari perencanaan, pengorganisasian, pelaksanaan, pengawasan dan evaluasi. Selanjutnya, harus diakui bahwa manajemen pengelolan selama ini berjalan ialah pola manajemen pengelolaan yang terhitung masih tradisional-konsumtif. Hal ini dapat diketahui dari beberapa hal di antaranya :pertama, kepemimpinan, yakni corak kepemimpinan dalam lembaga kenadziran masih sentralistik-otoriter (paternalistik) dan tidak ada sistem kontrol yang memadai. Kedua, rekruetmen sumber daya manusia ke nazhiran, yakni masih banyak nazhir wakaf yang hanya didasarkan pada aspek ketokohan seperti ulama, kyai, ustadz dan lain-lain, bukan aspek profesonalisme atau kemampuan dalam mengelola.Sehingga banyak benda-benda wakaf yang tidak terurus atau terkelola secara baik.

Ketiga, operasionalisasi pemberdayaan, yakni pola yang digunakan lebih kepada sistem yang tidak jelas (tidak memiliki standar operasional) karena lemahnya sumber daya manusi, visi dan misi pemberdayaa, dukungan political will pemerintah yang belum maksimal dan masih mengunakan sistem ribawi. Keempat, pola kemanfaatan hasil, yakni dalam menjalankan upaya pemanfaatan hasil wakaf masih banyak yang bersifat konsumtif-statis yaitu kurang dapat dirasakan manfaatnya oleh masyarakat banyak.Kelima, sistem kontrol dan pertannggungjawaban, yakni sebagai resiko dari pola kepemimpinan yang sentralistik dan lemahnya operasionalisasi pemberdayaan mengakibatkan pada lemahnya sistem kontrol baik yang 
bersifat kelembagaan maupun pengembangan usaha maupun keuangan (Depag RI, 2007: 105-106)

Sebagai upaya penting dalam pengembangan paradigma baru wakaf, maka sistem manajemen pengelolaan wakaf harus ditampilkan lebih profesional dan modern.Jadi asas profesionalisme ini harus dijadikan semangat pengelolaan harta benda wakaf dalam rangka mengambil kemanfaatannya yang lebih luas dan nyata untuk kepentingan masyarakat banyak.Dalam konteks ini, sesungguhnya Rasulullah SAW telah mengajarkan kepada kita bahwa segala sesuatu dan termasuk masalah yang berhubungan dengan manajemen apabila dilakukan dengan mengikuti sifat yang dimiliki Rasulullah SAW dapat dikategorikan sebagai perbuatan yang profesional.Hanya saja dapat kita pahami bahwa ukuran manajemen modern mengalami penafsiran dan perluasan makna yang lebih spesifik yang mana dalam teori dikenal dengan istilah TQM (Total Quality Management).Namun secara substansinya dapat dikerucutkan ke dalam empat hal yaitu :

1. Sidiq/jujur, yakni sifat mendasar baik yang terkait dnegan kepribadian sumber daya manusia maupun bentuk program yang ditawarkan sehingga konsumen atau masyarakat merasa tidak dimanfaatkan secara sepihak. Adapun bentuk program atau produk yang dipasarkan harus diinformasikan secara benar dan apa adanya.

2. Amanah/dapat dipercaya, yakni pola manajemen dikatakan profesional manakala seluruh sistem yang diterapkan dapat dipercaya, baik input atau out put-nya. Input sendiri dalam pengelolaan dapat dilihat dari sumber daya manusianya. Dalam konteks wakaf di sini bahwa nazhir setidaknya harus memiliki beberapa kriteria di antaranya :

a. Memiliki standar pendidikan tinggi dan standar moralitas yang baik, sehingga diharapkan proses yang dilakukannya dapat menghasilkan produk yang baik 
dan tidak merugikan orang lain atau wakif yang telah mempercayakan kepadanya untuk mengelola harta benda wakaf;

b. Memiliki skill yang bagus, sehingga dapat memberikan produk-produk yang berkualitas dan memiliki kelebihan dengan yang lain;

c. Adanya kejelasan dalam pembagian tugas (job description), sehingga tidak akan terjadi tumpang tindih wewenang, peran serta tanggung jawab;

d. Adanya standar hak dan kewajiban. Artinya bahwa diharapkan tidak ada ketimpangan antara hak dan kewajiban setiap masing-masing pihak yang terlibat dalam sebuah pengelolaan manajemen;

e. Adanya standar operasional yang jelas dan terarah, sehingga tidak akan terjadi kepincangan manajemen.

3. Tabligh/menyampaikan informasi yang benar / transparan, yakni sikap tabligh sesungguhnya lebih mengarah kepada kemauan dan kemampuan dalam menyampaikan segala bentuk informasi yang baik dan benar. Dalam manajemen, penyebaran informasi yang baik dan jujur akan sangat berkaitan dengan pola pemasaran dan pelaporan keuangan. Dalam hal ini stategi pemasaran haruslah mengikuti kaidah-kaidah hukum atau norma yang berlaku dimasyarakat sehingga tidak akan menimbulkan kecurigaan atau keresahan. Adapun dari aspek laporan keuangan haruslah meliputi transparansi, kejujuran dan akuntabilitas sehingga semua aliran uang siap untuk diaudit oleh pihak manapun dan kapanpun.

4. Fathanah/cerdas, yakni pengelola dalam hal ini haruslah memiliki kecerdasan utamanya diperlukan dalam menciptakan produk/ program yang dapat diterima oleh masyarakat dengan menawarkan berbagai harapan yang baik dan maju. Dalam hal wakaf misalnya pengelolaan benda-benda wakaf harus berbentuk usaha yang kiranya dapat membuka lapangan kerja baru dan dapat 
membantu pedagang kecil dan sebagainnya, sehingga hasilnya dapat dinikmati untuk kesejahteraan masyarakat luas.

Setidaknya dalam lembaga keNazhiran, potret kepemimpinan manajemen yang baik dalam pengelolaan harta benda wakaf dapat dilihat dari tiga aspek yaitu: pertama, transparansi. Dalam kepemimpinan manajemen profesional, transparansi menjadi ciri utama yang dilakukan oleh seorang pemimpin.Jika aspek transparansi diabaikan, maka dalam kepemimpinan tidaklah berjalan dengan baik bahkan membuka peluang penyelewangan yang tak terkendali.Trasnparansi ialah salah aspek penting yang tak terpisahkan dalam rangkaian kepemimpinan yang diajarkan oleh nilai-nilai Islam.Tentunya dalam konteks ini transparansi dalam lembaga keNazhiran harus dijadikan tradisi untuk menutup tindakan kejujuran, korupsi dan manipulasi dan lain sebagainya.

Kedua, pertannggungjawaban publik (public accountability). Dalam hal ini bentuk pertanggungjawaban tidak lain merupakan dari implementasi sifat amanah/dapat dipercaya dan shidiq/kejujuran, sebab kepercayaan dan kejujuran harus dapat dipertanggungjawabkan baik di dunia maupun akhirat nanti. sehingga dalam hal ini pula tidak ada manajemen "co boy" yaitu manajemen tunggal yang hanya terpusat dengan meniadakan keterbukaan yang sangat rentan terhadap penyimpangan dan kesewenang-wenangan.

Ketiga, aspiratif.Mengingat salah satu tujuan wakaf ialah menjadikannya sumber dana yang produktif, tentu memerlukan nazhir yang mampu melaksanakan tugastugasnya secara profesional dan bertanggung jawab. Nazhir yg dipercaya mengelola harta milik umum haruslah mendorong terjadinya sistem sosial yang melibatkan partisipasi banyaka kalangan, tujuannya ialah untuk menghindari pola pengambilan keputusan secara sepihak dikalangan elit kepemimpinan.Sesungguhnya aturan 
prinsip dalam gerakan aspiratif merupakan cermin dari sifat adil dalam diri atau lingkungannya dalam mendengar dan mengakomodir seluruh lembaga keNazhiran.

\section{Sistem Manajemen Pengelolaan Harta Benda Wakaf Oleh KeNazhiran}

Dalam kitab-kitab fikih, pada dasarnya ulama tidak mencantumkan nazhir wakaf sebagai salah satu rukun wakaf, disebabkan wakaf merupakan bentuk ibadah tabarru' yakni suatu pemberian yang bersifat sunnah. Meskipun demikian sesungguhnya eksistensi nazhir sangat dibutuhkan, sebab ditangan nazhir lah harta benda wakaf diharapka dapat terpelihara, dan terjaga serta mampu mengembangkan wakaf utamanya dalam menyalurkan hasil dan atau manfaat dari wakaf kepada sasaran wakaf (Depag RI, 2007: 116).

Nazhir wakaf yaitu badan atau orang yang memegang amanat untuk memelihara dan mengurus harta wakaf dengan sebaik-baiknya sesuai dengan wujud dan tujuannya.Dalam konteks ini, sesunggunya setiap orang dapat menjadi nazhir dengan syarat bahwa seseorang tadi berhak melakukan perbuatan hukum.Kemudian yang dimaksud nazhir berbadan hukum ialah kelompok orang yang merupakan satu pengurusan atau organisasi.Sementara itu, nazhir perseorangan adalah pemelihara wakaf yang dilakukan oleh individu (Khosyi'ah, 2010: 145).

Berdasarkan Pasal 1 ayat (4) Undang-Undang 41 Tahun 2004 tentang Wakaf, disebutkan bahwa nazhir adalah pihak yang menerima harta benda wakaf dari wakif untuk dikelola dan dikembangkan sesuai dengan peruntukannya. Menurut Undang-Undang ini nazhir atau nadir merupakan salah unsur atau rukun wakaf di samping wakif, harta benda wakaf, ikrar wakaf, peruntukan harta benda wakaf, dan jangka waktu wakaf. Adapun tugas dan kewajiban pokok nazhir tersebut yaitu mengelola dan 
mengembangkan wakaf secara produktif sesuai dengan tujuan, fungsi dan peruntukannya yang dilakukan sesuai dengan prinsip syariah.

Pengelolaan dan pengembangan benda wakaf secara produktif dimaksud dilakukan antara lain dengan cara pengumpulan, investasi, penanaman modal, produksi, kemitraan, perdagangan, agrobisnis, pertambangan, perindustrian, pengembangan teknologi, pembangunan gedung, apartemen, rumah susun, pertokoan, perkantoran, sara pendidikan, ataupun sarana kesehatan dan usahausaha yang tidak bertentangan dengan syariah. Namun sayangnya tidak sedikit kasus terkait pengelolan yang dilakukan oleh nazhir disebabkan salah satunya rendahnya kualitas sumber daya manusia yang dimiliki oleh nazhir sehingga berdampak tidak maksimalnya harta benda yang diwakafkan, bahkan tidak memberi manfaat sama sekali sesuai dengan peruntukannya (Usman, 2009: 135).

Untuk itulah kiranya penting bahwa nazhir harus memiliki kualifikasi profesionalitas sehingga padanya mampu me-manage dengan baik harta benda wakaf yang di amanatkan kepadanya.Paham profesionalitas yang harus dimiliki oleh nazhir tentunya didasarkan pada syarat-syarat sebagaimana disepakati oleh jumhur ulama yaitu beragama Islam, balig/dewasa, berakal, memiliki kemampuan dalam mengelola wakaf, memiliki sifat amanah, jujur, tablig, fathanah serta adil.Syarat-syarat tersebut hendaklah ditingkatkan supaya terwujud sistem manajemen yang baik dan handal dalam pengelolaan wakaf sehingga dapat bermanfaat untuk masyarakat luas sesuai sasarannya (Manan, 2006: 269).Apabila syarat-syarat nazhir di atas tidak terpenuhi, maka Hakim mesti menunjuk orang lain yang mempunyai hubungan kerabat dengan wakif dan dengan satu prinsip bahwa hak pengawasan ada pada wakif. Jika orang yang masih punya hubungan kerabat tersebut tidak ada, maka Hakim menunjuk orang lain (Suhadi, 1985: 28). 
Setidaknya terdapat beberapa alasan dalam rangka meningkatkan kemampuan nazhir diperlukan sistem manajemen sumber daya manusia yang handal, di antaranya yaitu :

Pertama, agar memiliki pengetahuan, kemampuan, dan keterampilan pada semua tingkatan dalam mengelola dan mengembangkan harta wakaf.Di samping itu perlu dibentuk sikap dan perilaku nazhir wakaf yang sesuai dengan jiwa profesionalisme dan bertanggung jawab dalam menjalankan kewajiban yang diberikan kepadanya.Kedua, memberikan pemahaman kepada nazhir terkait tata cara dan pola pengelolaan yang baik yang berorientasi pada kepentingan pelaksanaan syariat Islam secara luas dan dalam jangka panjang, sehingga wakaf dapat dijadikan sebagai elemen penting dalam menunjang penerapam sistem ekonomi syariah yang terpadu.Ketiga, menciptakan persepsi atau pola pikir yang sama dalam memahami sistem manajemen wakaf secara keseluruhan baik dari sisi perundang-undangan maupun teknis manajerial sehingga mudah untuk diadakan kontrol baik di daerah maupun pusat (Manan, 2009: 170).

Mengacu pada ketentuan Pasal 11Undang-Undang 41 Tahun 2004 tentang Wakaf, secara rinci tugas nazhir di antaranya yaitu :

1. Melakukan pengadministrasian harta benda wakaf;

2. Mengelola dan mengembangkan harta benda wakaf sesuai dengan tujuan, fungsi, dan peruntukannya;

3. Mengawasi dan melindungi harta benda wakaf;

4. Melaporkan pelaksanaan tugas kepada Badan Wakaf Indonesia.

Dengan melihat tugas dan tanggung jawab nazhir tersebut di atas, maka diperlukan proses rekrutmen yang selektif, dikarenakan nazhir sangat menentukan berhasil atau tidaknya wakaf dikembangkan. Di samping itu rekrutmen ini juga dimaksudkan supaya nazhir mudah untuk dibina.Upaya pembinaan yang harus dilakukan 
berdasarkan standar pola manajemen terkini yaitu dengan mengambil dari lulusan pendidikan formal misalnya jurusan pertanian yang diharapkan dalam mengelola dibidang persawahan, perkebunan, lading-ladang pembibitan dan lain sebagainya, jurusan teknk da pemasaran yang diharapkan mampu mengelola berbagai potensi benda wakaf secara produktif.

Selain pertimbangan pengambilan dari lulusan pendidikan formal, maka nazhir dalam hal ini perlu diberikan pendidkan tambahan atau non formal.Bentuk dari model pendidikan ini ialah dengan mengadakan peltihanpelatihan sumber daya manusia keNazhiran baik yang berhubungan dengan manajerial organisasi, atau meningkatkan ketarampilan dalam bidang profesi di antaranya administrasi, teknik pengelolaan pertanian, teknik perbankan, kepariwisataan, pemasaran dan lain sebagainya (Depag RI, 2007: 120).

Selama dalam menjalankan tugasnya, nazhir berhak menerima pengahsilan sebagai imbalan yang besarnya tidak melebihi $10 \%$ (sepuluh persen) dari hasil bersih atas pengelolaan dan pengembangan harta benda wakaf yang bersangkutan yang ditetapkan oleh Kantor Kemeterian Agama Kabupaten/Kota yang bersangkutan serta fasilitas lainnyayang diperlukan dalam rangka mengadministrasikan, mengelola, mengembangkan, mengawasi, dan melindungi harta benda wakaf yang menjadi tanggung jawabnya.

Mengacu pendapat Daud Ali yang dikutip Siah Khosyi'ah bahwa nazhir berhak mendapatkan upah dari jerih payah mengurus harta wakaf selama ia melaksanakan tugasnya dengan baik. Adapun besarnya sesuai dengan ketentuan wakif.Apabila wakif tidak menentukan besaran upah nazhir, maka hakim dapat menetapkan besarnya setiap bulan atau setiap tahun sesuai dengan berat ringannya tugas yang dibebankan kepadanya, sebab nazhir wakaf disini merupakan orang yang bertugas menjalankan 
amanat pemeliharaan dan pengurusan wakaf sesuai dengan wujud dan tujuannya, dan sebagai pemegang amanat.Pada dasarnya, nazhir tidak dibebani untuk menanggung resiko yang terjadi atas harta wakaf meskipun terjadi kerusakan atau kerugian karena kelalaian atau kesengajaannya disebabkan malas atau tidak pandai dalam memelihara atau mengurus harta wakaf (Khosyi'ah, 2010: 146).

Sehubungan dalam melaksanakan tugasnya, nazhir pada dasarnya juga berhak untuk mendapatkan arahan atau bimbingan dari lembaga yang berwenang dalam hal ini seperti Badan Wakaf Indonesia dengan memperhatikan saran dan pertimbangan dari majelis ulama Indonesia yang disesuaikan berdasarkan tingkatannya.Adapun pembinaan yang dimaksud di antaranya :pertama, penyiapan sarana dan prasarana penunjang operasional nazhir wakaf baik perseorangan, organisasi atau badan hukum. Kedua, penyusunan regulasi, pemberian motivasi, pemberian fasilitas, pengkoordinasian, pemberdayaan dan pengembangan terhadap harta benda wakaf.Ketiga, penyediaan fasilitas proses sertifikasi wakaf. Keempat, penyiapan dan pengadaan blangko-blangko akta ikrar wakaf, baik wakaf benda tidak bergerak atau benda tidak bergerak.Kelima, penyiapan penyuluh penerangan di daerah untuk melakukan pembinaan dan pengembangan wakaf kepada nazhir sesuai dengan lingkupnya.Keenam, pemberian fasilitas masuknya dana-dana wakaf dari dalam dari luar negeri dalam pengembangan dan pemberdayaan wakaf.

Untuk pembinaan terhadap nazhir harus dilakukan sekurang-kurangnya sekali dalam setahun dengan maksud dan tujuan untuk peningkatan etika dan moralitas dalam pengelolaan wakaf serta untuk peningkatan profesional manejemen wakaf.Bentuk kegiatan pembinaan dapat dilakukan dengan pihak ketiga yaitu melalui penelitian, pelatihan, seminar maupun kegiatan lainnya.selanjuttnya masa bakti nazhir yaitu 5 (lima) tahun dan dapat diangkat 
kembali oleh Badan Wakaf Indonesia apabila nazhir yang bersangktan telah melaksanakan tugasnya dengan baik dalam periode sebelumnya sebagaiman sesuai dengan ketentuan prinsip syariah dan peraturan perundangundangan. Namun dalam keadaan tertunda sesungguhnya nazhir dapat diberhentikan apabila yang bersangkutan yaitu meninggal dunia (bagi nazhir perseorangan), bubar atau dibubarkan sesuai dengan ketentuan peraturan perundang-undanagn yang berlaku untuk nazhir organisasi atau nazhir badan hukum, pengunduran diri, tidak melaksanakan tugasnya dengan baik atau telah melanggar ketentuan larangan dalam pegelolaan dan pengembangan harta benda wakaf sesuai dengan peraturan perundangundangan yang ada, dijatuhi hukuman pidana oleh pengadilan yang telah memiliki kekuatan hukum tetap (Usman, 2009: 138-139).

\section{Hikmah Adanya Nazhir Dalam Perwalian Wakaf}

Berbicara hikmah dalam pengelolaan wakaf baik yang dilakukan oleh nazhir perseorang maupun badan hukum dapat diketahui yaitu dapat membedayakan ekonomi umat sehingga tidak terdapat lagi benda-benda atau tanah wakaf yang terlantar akibat tidak adanya pengurusnya. Pada ranah yang lain perwalian dalam wakaf dapat menjadi peluang lapangan pekerjaan bagi umat Islam khususnya mereka yang memiliki kualifikasi atau keahlian dalam mengurus harta wakaf.

Keberadaan nazhir dalam harta wakaf tentunya tidak akan terjadi saling menuduh dalam pemeliharaan harta wakaf yang saling berebutan, dan disaat ada hasilnya tidak adanya orang yang bertanggung jawab atas pengelolaanya. Pengurusan harta wakaf yang dilakukan oleh badan hukum atau nazhir yang ada di masyarakat akan menjadikan ajang peningkatan ekonomi umat bagi lembaga-lembaga swadaya masyarakat yang berdasarkan Islam, dikarenakan pada dasarnya mereka dapat 
mengajukan gugatan atas harta wakaf. Maka, dengan adanya nazhir, diharapkan status harta benda wakaf tetap terjaga dan tidak terjadi sengeketa dikemudian hari. Nazhir dalam hal ini juga berkewajiban menyimpan akta ikrar wakaf yang tidak lain merupakan legalisasi dari harta wakaf itu menjadi penolak terjadinya gugatan. Meskipun tidak dipungkiri bahwa tidak sedikit harta benda wakaf yang terjadi di masyarakat seringkali berubah menjadi orientasi bisnis dan bahkan hilangnya harta wakaf, hal demikian itu dikarenakan pengelola yang tidak memiliki sifat amanah dalam menjalankan tugasnya, namun demikian dengan adanya ikrar akta wakaf sekarang ini diharapkan akan mampu menghindarkan segala macam bentuk penyelewengan atas harta benda wakaf.

\section{Keberadaan Badan Wakaf Indonesia Dalam Pembinaan dan Pengembangan Perwakafan}

Salah satu elemen penting dalam pembaharuan kepemimpinan manajemen perwakafan ialah kehadiran lembaga yang profesional sebagai perwujudan representasi dari pola pembinaan dan pengawasan atas kepemimpinan manajemen perwakafan di Indonesia.Secara filosofis, pembentukan Badan Wakaf Indonesia dimaksudkan sebagai lembaga independen yang bertugas untuk memajukan dan mengembangkan perwakafan nasional di Indonesia. Lebih lanjut, dijelaskan dalam Undang-Undang 41 Tahun 2004 tentang Wakaf, dalam menjalankan tugas dan wewenangnya tersebut, susunan organisasi Badan Wakaf Indonesia terdiri atas badan pelaksana dan dewan pertimbangan.

Selanjutnya, badan pelaksana Badan Wakaf Indonesia merupakan unsur pelaksana tugas badan wakaf Indonesia dan Dewan Pertimbangan Badan Wakaf Indonesia merupakan unsur pengawas pelaksanaan tugas Badan Wakaf Indonesia. Badan Pelaksana dan Dewan Pertimbangan Badan Wakaf Indonesia masing-masing 
dipimpin oleh 1 (satu) orang ketua dan 2 (dua) orang Wakil Ketua yang dipilih dari dan oleh para anggota. Susunan keanggotaan masing-masing Badan Pelaksana dan Dewan Pertimbangan Badan Wakaf Indonesia ditetapkan oleh anggota (Usman, 2009: 134).

Badan Wakaf Indonesia di atas beranggota paling sedikit 20 (dua puluh) orang dan paling banyak 30 (tiga puluh) orang yang berasal dari unsur masyarakat. keanggotaan Badan Wakaf Indonesia diangkat dan diberhentikan oleh presiden untuk masa jabatan selama 3 (tiga) tahun dan dapat diangkat kembali untuk 1 (satu) kali masa jabatan, adapun keanggotaan perwakilan Badan Wakaf Indonesia di daerah angkat dan diberhentikan oleh Badan Wakaf Indonesia.Secara organisatoris Badan Wakaf Indonesia dalam menjalankan tugasnya harus bersifat independen, dimana pemerintah dalam hal ini sebagai fasilitator, regulator, motivator dan pengawasan.Tugas utama lembaga ini ialah memberdayakan wakaf, baik wakaf benda tidak bergerak maupun benda bergerak yang ada di Indonesia sehingga dapat memberdayakan ekonomi umat.

Tugas Badan Wakaf Indonesia lainnya yaitu melakukan pembinaan terhadap nazhir dalam mengelola dan mengembangkan harta benda wakaf, melakukan pengelolan dan mengembangkan harta wakaf berskala nasional dan internasional, memberikan persetujuan dan atau ijin atas perubahan peruntukan dan status harta benda wakaf, memberhentikan dan mengganti nazhir, memberikan atas penukaran harta wakaf, dan memberikan dan pertimbangan kepada pemerintah dalam penyusunan kebijakan di bidang perwakafan. Dalam menjalankan tugas tersebut Badan Wakaf Indonesia dapat bekerja sama dengan instansi pemerintah baik Pusat maupun Daerah, organisasi masyarakat, para ahli, badan internasional, dan pihak lain yang dipandang perlu serta memperhatikan saran dan pertimbangan menteri yang bertanggung jawab di bidang agama dan Majelis Ulama Indonesia. 
Sejalan dengan tugas-tugas yang dibebankan kepada Badan Wakaf Indonesia yang cukup berat, maka keberadaan Badan Wakaf Indonesia disini haruslah ditingkatkan profesionalitasnya, sehingga pola organisasi dan kelembagaan badan wakaf dapat merespon segala bentuk permasalahan-permasalahan yang tengah dihadapi masyarakat, utamanya berkaitan dengan kesehatan, kemiskinan, pendidikan dan lain sebagainya. Dalam rangka peningkatan profesionalitas Badan Wakaf Indonesia dalam mengelola harta benda wakaf, maka perlu kiranya meningkatkan sumber daya manusia anggota, berdedikasi tinggi dan memiliki komitmen dalam pengembangan wakaf serta memahami persoalan-persoalan wakaf (Manan, 2006: 267).

Jika dipahami Badan Wakaf Indonesia sebagai garda depan dalam pembinaan dan pengembangan harta benda wakaf yang dilakukan oleh nazhir, namun hal yang juga penting untuk diperhatikan adalah pemberdayaan lembagalembaga kenazhiran yang sudah ada selama ini dengan melalui penataan tugas-tugas kenazhiran secara maksimal terlebih memperbaiki dalam mekanisme kelembagaan, sebab selama ini lembaga nazhir dikuasai secara terpusat oleh beberapa kepengurusan saja. Bagaimana kepengurusan yang baik tentunya tergantung dari situasi dan kondisi dilapangan, namun yang terpenting pada ranah organisasi adalah bagaimana mewujudkan pengaturan pengorganisasian yang sehubungan pengambilan keputusan melalui musyawarah, pengelolaan keuntungan, pertanggungjawaban kepengurusan dan pengawasan pelaksanaan kelembagaan (Depag RI, 2007: 108).

\section{E. Simpulan}

Manajemen sesungguhnya memainkan peranan penting dalam merealisasikan tujuan-tujuan maupun sasaran-sasaran organisasi maupun pribadi, dalam konteks ini tak terkecuali organisasi dan atau lembaga kenazhiran 
maupun perseorangan dalam pengelolaan dan pengembangan harta benda wakaf yang sesuai dengan peruntukannya. Dengan perkataan lain baik dan buruknya pengelolaan harta benda wakaf, maka sangat ditentukan dari sistem manajemen yang digunakan.Untuk itu, guna tercapainya efektif dan efesiensi dalam pengelolaan harta wakaf, maka setidaknya perlu dilakukan pembaharuan paham manajemen khususnya bagi pengelola dalam hal ini nazhir yang mana keberadaannya sangat penting dalam menjaga, dan mengembangkan wakaf agar wakaf dapat berfungsi sebagaimana yang diharapkan.

Dapat dipahami bahwa pola kepemimpinan manajemen pengelolaan harta benda wakaf yang selama ini masih dipandang sebagai pola manajemen yang terhitung konservatif-konsumtif dan atau konsumtif-statis yaitu kurang dapat dirasakan manfaatnya oleh masyarakat luas, maka untuk menampilkan pengelolaan yang profesional perlu dilakukan perubahan paham terhadap sistem manajemen pengelolaan wakaf misalnya dari aspek kenazhiran, perlu meningkatkan SDM nazhir wakaf pada semua tingkatan dalam rangka membangun kemampuan manajerial yang tangguh, profesional, dan bertanggung jawab, serta membentuk perilaku (moral) nazhir sesuai dengan posisi yang seharusnya, yaitu menjaga amanat dari wakif yang telah mempercayakan harta benda untuk dikelola secara baik dan dapat dipertanggungjawabkan dihadapan Allah SWT. Kemudian dari aspek lain yaitu kelembagaan Badan Wakaf Indonesia merupakan lembaga yang diberikan tugas mengembangkan wakaf secara produktif, sehingga wakaf dapat berfungsi untuk meningkatkan taraf hidup masyarakat, di samping bertugas melakukan pembinaan terhadap nazhir lebih-lebih terkait dengan memperbaiki dalam mekanisme kelembagaanya. Maka, secara organisatoris Badan Wakaf Indonesia dalam menjalankan tugas dan kewenanganya haruslah bersifat 
Memahami Pola Pembaharuan Paham Kepemimpinan ...

independen, dimana pemerintah dalam hal ini sebagai fasilitator, regulator, motivator dan pengawasan.

\section{DAFTAR PUSTAKA}

Abdul Manan, Aneka Masalah Hukum Perdata Islam di Indonesia, Kencana Prenada Media Group, Jakarta, 2009.

Abdurrahman Kasdi, Peran Nazhir Dalam Pengembangan Wakaf, Jurnal Ziswaf, Vol. 1, No. 2, Desember 2014.

Abu Abd Al-Lah Ahmad Ibn Ismail, Matan Shahih AlBukhari, Ibn Hasyiah Al Sindi, Maktabah Ahmad, Mesir, tt.

Departemen Agama Republik Indonesia, Paradigma Baru Wakaf di Indonesia, Direktorat Pemberdayaan Wakaf Direktorat Jenderal Bimbingan Masyarakat Islam, Jakarta, 2007.

Imam Suhadi, Hukum Wakaf di Indonesia, Dua Dimensi, Yogyakarta, 1985.

Made Pidarta, Manajemen Pendidikan Islam, Bina Aksara, Jakarta, 1989.

Rachmadi Usman, Hukum Perwakafan di Indonesia, Sinar Grafika, Jakarta, 2009.

Syafaruddin, Manajemen Lembaga Pendidikan Islam, Cet. 1, Ciputat Press, Jakarta, 2005. 
Junaidi Abdullah dan Aristani

Siah Khosyi'ah, Wakaf dan Hibah; Dalam Perspektif Ulama Dan Fikih Dan Perkembangannya di Indonesia, Pustaka Setia, Bandung, 2010.

T. Hani Handoko, Manajemen, Edisi 2, BPFE, Yogyakarta, 1984. 